\title{
The Role of Open Government Data in Urban Areas Development
}

\author{
Lorena BĂTĂGAN \\ Bucharest University of Economic Studies, Romania \\ lorena.batagan@ie.ase.ro
}

The next step for our urban areas is to become friendly using open data. The focus of this paper is to highlight the necessity and the implementation of Open Government Data (OGD). It also presents the principles of Open Government Data. The paper aims to analyze the OGD solutions and the impact of these for urban development using a SWOT analysis. In our age OGD confers an important advantage in development economy. In this case everybody tries to implement efficient $O G D$.

Keywords: Open Data, Open Government Data, Smart Cities, Friendly Cities, Knowledge Economy

\section{1} Introduction

The paper aims to analyze the impact and the role of open government data in our society and to highlight the trend of European countries in this case.

The first part presents the literature review of the open data and open government data. Researchers worldwide are interested in improving governmental activity by implementing the latest innovations to the knowledge economy. The free exchange of ideas, information and knowledge is the support of development [14]. Open data is an essential element for knowledge economy. Knowledge economy emphasizes with lifelong learning, good quality of life and open government data.

The second part highlights the opportunities and the changes that will be made in society after will implement an OGD solution. It is essential to the governmental and the citizens to use open data because this will offer independence, transparency, decentralization and, in the same time, aggregation.

The third and the fourth part of the paper present the impact and the barriers of open government data. It is very important to highlight the benefits, disadvantages and barriers. These can be presented start from the most important cities how use this kind of solutions. In the fifth part is presented a classification of cities in three main categories based on the usage of open government data and a SWOT analysis about OGD solutions.
The paper ends with the conclusion and the most important idea is: for development urban areas we have to use open government data.

\section{Literature Review}

The literature review [1], [2], [3] highlight that a group inspired by open source software movements published version 1.0 of a statement they called the Open Knowledge Definition (OKF - Open Knowledge Foundation, 2006). This puts forward a definition of what it means to have open content, stating that: "A piece of data or content is open if anyone is free to use, reuse, and redistribute it - subject only, at most, to the requirement to attribute and/or sharealike" [6], [7], [8].

In our age we can increasing the efficiency of public services and governmental activities by fast adopting the new technologies and the open data solutions.

The most recent and important point of view is use of open data solutions is the Europe 2020 Strategy [18], [22], [23]. This strategy try to put the Europe's economy back on the path to growth.

The Europe 2020 Strategy promotes the strategic objectives of a smart, sustainable and inclusive growth which are made further operational by a number of five headline targets for 2020 and by seven flagship initiatives. 
To improve the employment rate of the population aged 20-64 from the current $69 \%$ to at least $75 \%$.

To achieve the target of investing $3 \%$ of GDP in R\&D in particular

by improving the conditions for R\&D investment by the private

sector, and develop a new indicator to track innovation.

To increase the share of renewable energy in final energy

consumption to $20 \%$, and achieve a $20 \%$ increase in energy

efficiency.

To reduce the share of early school leavers. The EU objectives are to

$10 \%$ from the current $15 \%$ and increase the share of the population

aged $30-34$ having completed tertiary from $31 \%$ to at least $40 \%$.

To reduce the number of poverty people. Here the accent is put on

the lifting 20 million people out of poverty.

Fig. 1. The five headline targets of Europe 2020 Strategy ([18],[22], [23])

The Europe 2020 Strategy identifies five headlines that European Union should take to boost growth and employment. These are presented in Figure 1.

The Europe 2020 Strategy has important direct implications for the future $\mathrm{EU}$ Cohesion Policy, because it develops - in fact - the same strategies for the period 20142020. The Europe 2020 Strategy identifies seven flagship initiatives. These flagship initiatives [18], [23] are (Figure 2):

- Innovation Union: the most important aspect is to improve framework conditions for better finance of research and innovation;

- youth on the move: to reinforce the education systems and to improve the international view of Europe's higher education;

- a digital agenda for Europe: the accent is put on the development of high-speed internet and to use the benefits of the one digital market;

- resource efficient Europe: to use efficiently the resources for economic growth, increasing the use of renewable sources, improve and modernizing the transport sector and reduce of energy consume;

DOI: 10.12948/issn14531305/18.2.2014.08
- an industrial policy for the globalization era: the most important objectives are to improve the business environment and to development of a strong and sustainable industrial base able to compete globally.

- an agenda for new skills and jobs: to modernize activities by facilitating mobility and the development of skills throughout the lifecycle;

- European platform against poverty: to ensure social and territorial cohesion.

In this context the use of new solutions of Information Communication and Technology (ICT) for a modern governance is fundamental for development.

Information Society is the foundation of modern and efficient governance. Creativity becomes an important part of each economic, social and administrative structure. ICT implementation in governance can pass over the limitations of traditional governmental practices.

The actual governance is characterized by the efforts made by the governments to improve the communication with the citizens through open data solutions. In the last years the most important open government initiative is to increase the volume of government data sent to citizens via the Internet. The transparency and openness, given by the principles of In- 
ternet brought the governments more closely by their citizens.
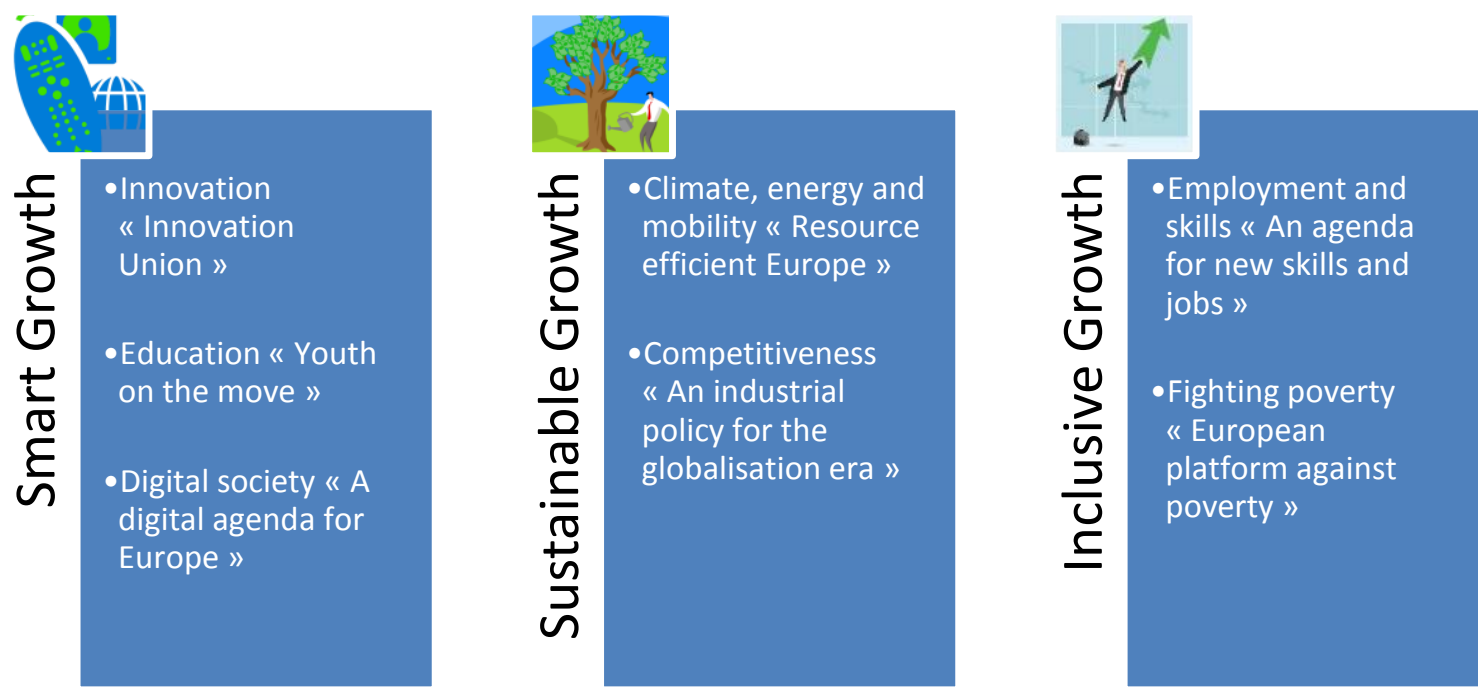

Fig. 2. The seven flagship initiatives of Europe 2020 Strategy

Because the EU wants to promote openness, in the Open Data Charter - the report [23] regarding the open data, they committed to:

- identify and make available core and high-value datasets held at EU level;

- publish data on the EU Open Data Portal;

- promote the application of these principles of Open Data Charter in all 28 EU Member States;

- support activities, outreach, consultation and engagement;

- share experiences of work in the area of open data.

From the beginning, the most important use of open data is in governmental area because this can improve the communication, cost and transparency.

\section{Research Methodology \\ Research problem}

The main question of this research is: "What is the impact and role of Open Government Data in the urban areas?"

Research design

The research is exploratory, and it is based on documentary study. In the paper are dis- cussed the main issues regarding the benefits of open government data, necessity of open government and about the use of open government data. The findings were structured on: characteristics regarding the use of open government data and models of using open government data.

In this paper is presented a SWOT analysis on the impact of open government data.

Sample, population or subjects

The sample consists of the most relevant papers, studies and applications about open government data.

\section{The Impact of Open Government Data}

The study about the impact of open government data must to start from the definition of open data. In this content anyone is free to use or reuse a piece of data for his interest but is important to highlight the source. Based on it the firms and institutions can reuse freely the available government information in innovative ways. It is evident that the OGD influence the activity of the government (public), business and industry (private), NGO and citizens (Figure 3). 


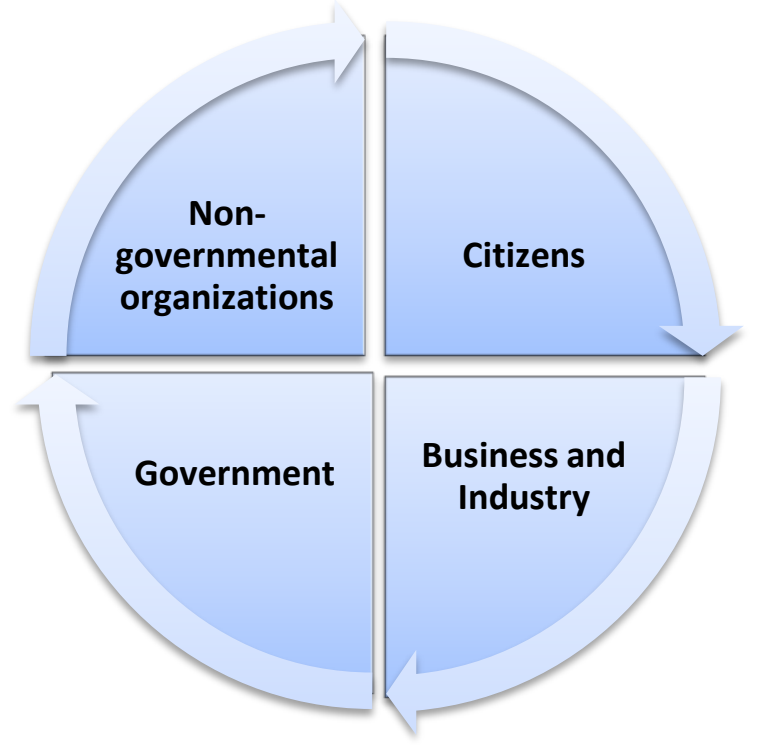

Fig. 3. Open data ecosystem

OGD [16] have an important impact in every part of our society: economic, social and political. From economic part we can identify three important benefits of open government data: improve quality of life, increased GDP, reduction in data transaction costs and increased service efficiency. The most important political benefits for government by using open government data are increased transparency and accurate of information. Social benefits of open government data have on base the increasing of inclusion.

On the other part to highlight the implication of OGD is very important to highlight the benefits of opening data to government, business and industry, non-governmental organizations and citizens. In this case Granickas and Tinholt ([4], [5], [13]) analyzed and identified that for any part of our society we can point a big number of benefits (Table 1).

Table 1. Benefits of Open Government Data

\begin{tabular}{|l|l|l|}
\hline \multicolumn{1}{|c|}{ Benefit to government } & \multicolumn{1}{c|}{$\begin{array}{c}\text { Benefit to } \\
\text { private sector }\end{array}$} & \multicolumn{1}{c|}{$\begin{array}{c}\text { Adapted from: [13] and [5] } \\
\text { Benefit to } \\
\text { civil society }\end{array}$} \\
\hline $\begin{array}{l}\text { Increased tax revenues } \\
\text { through increased economic } \\
\text { activity }\end{array}$ & $\begin{array}{l}\text { New business opportuni- } \\
\text { ties for services / goods }\end{array}$ & Better informed monitoring \\
\hline $\begin{array}{l}\text { Creation jobs } \\
\text { Reduction in data transaction } \\
\text { costs }\end{array}$ & $\begin{array}{l}\text { Reduced costs for data } \\
\text { transmission and conver- } \\
\text { sion }\end{array}$ & $\begin{array}{l}\text { New venues for project action: } \\
\text { building tools/applications }\end{array}$ \\
\hline Increased service efficiency & $\begin{array}{l}\text { Better decision-making } \\
\text { based on accurate infor- } \\
\text { mation }\end{array}$ & $\begin{array}{l}\text { Increased sustainability potential } \\
\text { through increased capacity }\end{array}$ \\
\hline Transparent Activity & $\begin{array}{l}\text { Transparence infor- } \\
\text { mation }\end{array}$ & Build a transparent society \\
\hline Increased GDP & Access to information & Access to information \\
\hline $\begin{array}{l}\text { Encouraged entrepreneurship } \\
\text { (economic growth) }\end{array}$ & Better-skilled workforce & \\
\hline
\end{tabular}

It is very important to highlight that the gov- ernment agencies in every country hold vast 
stores of data, which, if made open, could enable the creation of large amounts of economic value. Making government data available not only enables value creation, but also sets the direction for openness among other institutions.

\section{Barriers to Open Government Data}

After a long literature review in this domain it is evident that the number of paper about barriers to open government data has been less extensive than the studies about benefits. The most important barriers which are determinate of the government organizations are:

- don't have a coherent vision for support open data;

- don't have enough financial resources;

- don't know how to promoting open data use.

On the other hand the most important barriers which are determinate of the citizens are related to the quality of data and data protection.

But, the researchers [3], [9], [12] from all the world are agree that the barrier to open government data exist. Based on [1], [2] and [3] we can classify the barriers in eight headings:

- economic-resources, funding

- technical - standards, technical capacity

- cultural - organizational cultural

- administrative - security, policy

- legal-legislation, licensing

- quality - language differences

- cost - provisioning and delivery

- risk - data protection.

From these we can accentuate three elements with important impact: cost of provisioning and delivery data (data is most often stored on servers), the language barrier and the legislative changes. It is very good when we try to implementing OGD solutions to take into account the barriers described above, so them to be avoided.

We expect OGD solutions to generate value and substantial returns through increased transparency, efficiency and cooperation of government activities, citizen participation and entrepreneurial activity.

\section{Open Government Data Initiatives}

In the world we can find OGD solutions implemented in many countries. The UK Government has opened up over 8.000 unique datasets on data.gov.uk and thought affiliated sites such as data.london.gov.uk [17]. Many other countries and cities have open government data. Governmental organizations from all over the world are a huge producer of data including maps, satellite images and statistics. This government data is produced by public authorities during their everyday work in order to accomplish their goals.

The exploration of use of open government data is not an easy study because we must to centralize the information from every governmental organization. The researchers from the Capgemini Consulting [13] in their analysis identified the most popular countries, where are implemented OGD solutions: USA, UK, Canada, Australia, Sweden, Germany and France.

In the last years, government organizations from many countries publish a variety of data on the web to enable transparency, foster applications, and to satisfy legal obligations.

In our country we can find [11] a list of projects with include open data solutions:

- E-Procurement

- Unique Identification of Public Servants

- E-Tax Payment

- Document Management

- Integrated Resource Planning

- Cash Flow Management

- Citizens' Information Centers

- Info kiosks for Citizens

- E-Referendum

- E-Jobs

- E-Europe Status

- Portal for Address Change Notification

- The National Electronic System

The literature review [11], [15] highlight that Romania has adopted in time all EU directives and now has a good legal framework regarding citizen engagement and electronic government [20].

For the moment in every country is a trend or a necessity to use to the right value the openness of data in government organizations. 


\section{Results and Discussions}

After analyzing the literature and professional practice we have identified the following characteristics regarding the use open government data:

- different initiatives have the ability to create value of both social and economic nature for both the private and public sector [10];

- different levels and types of investment in processes and technology are needed as well as different data sets, licenses and even business models;

- open data increased citizen participation and collaboration;

- improved quality and governance of government data.

Start for these elements and have in view the three core principles of Open Government Data: transparency, participation, and collaboration [21] we can development a SWOT analysis (Table 2).

Table 2. SWOT Analysis of OGD

\begin{tabular}{|c|c|c|c|c|}
\hline \multirow{2}{*}{ Principles } & \multicolumn{4}{|c|}{ Impact of OGD } \\
\hline & Strengths & Weaknesses & Opportunities & \begin{tabular}{|c|} 
Threats \\
\end{tabular} \\
\hline Transparency & $\begin{array}{l}\text { - Creation of } \\
\text { data sets used } \\
\text { in any context } \\
\text { of everybody; }\end{array}$ & $\begin{array}{l}\text { The need for a } \\
\text { standardiza- } \\
\text { tion process; } \\
\text { High cost to } \\
\text { maintain the } \\
\text { security of } \\
\text { ICT and } \\
\text { transparency; }\end{array}$ & $\begin{array}{l}\text { Reducing cor- } \\
\text { ruption and } \\
\text { increasing } \\
\text { transparency; }\end{array}$ & $\begin{array}{l}\text { Violation of the } \\
\text { rules relating to } \\
\text { private data; }\end{array}$ \\
\hline Participation & $\begin{array}{l}\text { - Increased par- } \\
\text { ticipation of } \\
\text { citizens; } \\
\text { - A consistent } \\
\text { feedback on } \\
\text { regulations or } \\
\text { administrative } \\
\text { proceedings; }\end{array}$ & $\begin{array}{l}\text { High costs of } \\
\text { maintenance } \\
\text { and data col- } \\
\text { lection related } \\
\text { to intensify; } \\
\text { - The need for } \\
\text { good employ- } \\
\text { ers how con- } \\
\text { tinuously up- } \\
\text { date their } \\
\text { knowledge; }\end{array}$ & $\begin{array}{l}\text { - Increase in- } \\
\text { teroperability } \\
\text { between gov- } \\
\text { ernment insti- } \\
\text { tutions at na- } \\
\text { tional and in- } \\
\text { ternational } \\
\text { levels; }\end{array}$ & $\begin{array}{l}\text { - Misinterpretation } \\
\text { of data; } \\
\text { - Misunderstanding } \\
\text { of the meaning of } \\
\text { certain data; }\end{array}$ \\
\hline Collaboration & $\begin{array}{l}\text { - Increase col- } \\
\text { laboration be- } \\
\text { tween gov- } \\
\text { ernment, on } \\
\text { the one hand } \\
\text { and citizens } \\
\text { and business, } \\
\text { on the other } \\
\text { hand. }\end{array}$ & $\begin{array}{l}\text { A uniform } \\
\text { approach to } \\
\text { implementing } \\
\text { Open Gov- } \\
\text { ernment in the } \\
\text { various busi- } \\
\text { ness and sec- } \\
\text { tors. }\end{array}$ & $\begin{array}{l}\text { - Modernization } \\
\text { of administra- } \\
\text { tive proce- } \\
\text { dures; } \\
\text { - Creating a } \\
\text { civic culture } \\
\text { among citi- } \\
\text { zens. }\end{array}$ & $\begin{array}{l}\text { Encourage con- } \\
\text { structive criti- } \\
\text { cism. }\end{array}$ \\
\hline
\end{tabular}

Open government data is essential for the transparency and efficiency of the governance and for citizen participation in decision making process.

\section{Conclusions}

To implement an OGD solution represent an important step for development of our country and this will have a higher impact to quality of life, access information, improve ser- 
vice efficiency, reduction in data transaction costs and improve the performance of activity and build new business opportunities. More and more governments start to use OGD for their citizens and these receive great interest because they are very useful. It is essential for our cities today to use OGD to link data. Our urban areas which are using OGD are become friendlier for citizens and for business and non-governmental organizations.

\section{Acknowledgment}

This work was supported from the COST Action no. TU1204 Action Title: "People Friendly Cities in a Data Rich World".

Parts of this research have been published in the Proceedings of the $13^{\text {th }}$ International Conference on Informatics in Economy, IE 2014.

\section{References}

[1] E. Barry, F. Bannister, Barriers to Open Data Release: A View from the Top, 2013 [Online]. Available at: https://www.scss.tcd.ie/disciplines/infor mation_systems/egpa/docs/2013/ BarryBannister. pdf, [May, 2014].

[2] D. Cvetkovic, Open Data and Cities, 2013 [Online]. Available at: http://www.microsoft.com/global/eu/Ren deringAssets/pdf/Open\%20Data\%20for $\% 20$ Cities\%20-

\%20Dejan\%20Cvetkovic.pdf, [May, 2014].

[3] T. Davies, F. Perini, and J. M. Alonso, Researching the emerging impacts of open data, July 2013 - ODDC (Open Data in Developing Countries) conceptual framework [Online]. Available at http://www.opendataresearch.org/sites/d efault/files/

posts/Researching\%20the\%20emerging $\% 20 \mathrm{impacts} \% 20 \mathrm{of} \% 20$ open\%20data.pdf , [May, 2014].

[4] L. Ding et al., TWC LOGD: A portal for linked open government data ecosystems, Web Semantics: Science, Services and Agents on the World Wide Web, 9(3), 325-333, 2011 [May, 2014].

[5] K. Granickas, Understanding the impact of releasing and re-using open government data, European Public Sector Information Platform, Topic Report No. 8/2013 [Online]. Available at: http://www.epsiplatform.eu/sites/default/ files/2013-08-Open_Data_Impact.pdf, [May, 2014].

[6] K. Janssen, The influence of the PSI directive on open government data: An overview of recent developments. Government Information Quarterly, 28(4), 2011, pp. 446-456. [May, 2014].

[7] M. Janssen, Y. Charalabidis, and A. Zuiderwijk, Benefits, Adoption Barriers and Myths of Open Data and Open Government. Information Systems Management (ISM), vol. 29, no.4, 2012 pp. 258268.

[8] V. Kundra, Digital Fuel of the 21st Century: Innovation through Open Data and the Network Effect, Harvard University 2011 [Online]. Available at: http://www.hks.harvard.edu/presspol/pu blications/papers/discussion_papers/d70 _kundra.pdf, [May, 2014].

[9] S. Martin, M. Foulonneau, S. Turki and M. Ihadjadene, Risk Analysis to Overcome Barriers to Open Data [Online]. Available at: www.ejeg.com/issue/download.html?id Article=296, [May, 2014].

[10] T. Jetzek, M. Avital and N. BjornAndersen, The Value of Open Government Data: A Strategic Analysis Framework, SIG eGovernment pre-ICIS Workshop, Orlando 2012 [Online]. Available at:

http://openarchive.cbs.dk/bitstream/hand le/10398/8621/Jetzek.pdf?sequence $=1$, [May, 2014].

[11] A. Stoiciu. Open Government Data and Citizen Engagement in Romania, Future Government: A Global perspective in Connection to Open Government Data and Citizen Engagement, 2012 [Online]. Available at: http://unpan1.un.org/intradoc/groups/pub lic/documents/undpadm/unpan049449.pdf, [May, 2014].

[12] J. Surowiecki. The Wisdom of Crowds: 
Why the Many Are Smarter Than the Few and How Collective Wisdom Shapes Business Economies, Societies and Nations: Doubleday 2004 [Online]. Available at: http://kittur.org/files/Wisdom\%20of\%20 Crowds_Ch1.pdf, [May, 2014].

[13] D. Tinholt, The Open Data Economy Unlocking Economic Value by Opening Government and Public Data, Capgemini Consulting 2013 [Online]. Available at: http://www.capgeminiconsulting.com/resource-fileaccess/resource/pdf/opendata_pov_6feb.pd f, [May, 2014].

[14] Organization for Economic Cooperation and Development, 2007. OECD Principles and Guidelines for Access to Research Data from Public Funding, [Online]. Available at: http://www.oecd.org/sti/scitech/38500813.pdf, [May, 2014].

[15] D. Banciu, Guvernarea Deschisă: De la teorie la realitate.Cazul României, Institutul Naţional de CercetareDezvoltare în Informatică - ICI București [Online]. Available at: http://www.computerworld.ro/wpcontent/uploads/2013/11/Prezentare-_Doina-banciu.pdf , [May, 2014].

[16] Open Knowledge Foundation, 2014. What is Open Government Data [Online]. Available at: http://open governmentdata.org/, [May, 2014].

[17] Deloitte, 2013. Open data - Driving growth, ingenuity and innovation, Deloitte [Online]. Available at: http://www.deloitte.com/assets/dcom- unitedkingdom/local\%20assets/documen ts

/market\%20insights/deloitte\%20analytic s/uk-insights-deloitte-analytics-opendata-june-2012.pdf, [May, 2014].

[18] A resource-efficient Europe - Flagship initiative under the Europe 2020 Strategy [Online]. Available at: http://ec.europa.eu/resource-efficienteurope/pdf/resource_efficient_europe_en.p df, [May, 2014].

[19] Principles of Open Government: Transparency, Participation \& Collaboration, August 2012 [Online]. Available at: http://www.library.ca.gov/crb/12/S-12003.pdf, [May, 2014].

[20] Eurostat regional yearbook 2012, [Online]. Available at: http://epp.eurostat.ec.europa.eu/cache/IT Y_OFFPUB/KS-HA-12-001/EN/KS-HA12-001-EN.PDF, [May, 2014].

[21] e-Government: PESTLE \& SWOT Analysis, FORSEE Partnership, 2012

[Online]. Available at: http://forsee.eu/documents/227_FORSEE _SWOT_analysis_eGov_152.pdf, [May, 2014].

[22] ANNEX 1 - EUROPE 2020: An overview [Online]. Available at: http://www.eudirect.ro/utile/annex1.pdf, [May, 2014].

[23] EU implementation of G8 Open Data Charter, 2013, Brussels: EU [Online]. Available at: http://ec.europa.eu/digitalagenda/en/news/eu-implementation-g8open-data-charter, [May, 2014].

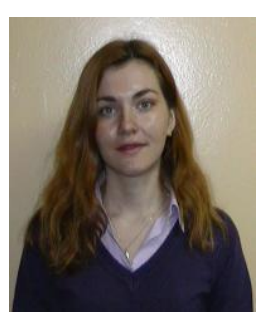

Lorena BĂTĂGAN has graduated the Faculty of Cybernetics, Statistics and Economic Informatics in 2002 when she has become teaching assistant. Currently she is associate professor at the Faculty of Cybernetics, Statistics and Economic Informatics from Bucharest University of Economic Studies. She holds a PhD degree in Economic Cybernetics and Statistics since 2007. She is the author and co-author of 4 books and over 50 articles in journals and proceedings of national and international conferences and symposiums. 